\title{
Not Known if Additional Testing Was Performed
}

National Cancer Institute

\section{Source}

National Cancer Institute. Not Known if Additional Testing Was Performed. NCl

Thesaurus. Code C160303.

An indication that it is not known whether additional tests were performed during the study. 